\title{
Realizações Orais dos Ditongos Ortográficos em Língua Jnglesa
}

\author{
Alexandre STEIN* \\ Dircel Aparecida KAILER**
}

\begin{abstract}
* Doutor (2020) em Estudos da Linguagem pela Universidade Estadual de Londrina. Professor de Língua Inglesa com experiência no setor privado e no setor público. Contato: alexandrestein02@gmail.com.
\end{abstract}

** Doutora (2008) em Linguística e Língua Portuguesa pela Universidade Estadual Paulista (UNESP-Araraquara). Docente da Universidade Estadual de Londrina. Contato: ueldircel@hotmail.com.

\section{Resumo:}

O presente artigo tem como objetivo apresentar uma análise de como aprendizes brasileiros de Língua Inglesa realizam oralmente os ditongos ortográficos desta língua. Como fundamentação teórica, buscamos embasamento nos princípios da Aquisição de Segunda Língua, Variação Linguística em L2 e nos pressupostos da Interlíngua, da Consciência Fonológica e nos estudos sobre a influência grafo-fônico-fonológica em L2. O corpus analisado é constituído de 52 palavras grafadas com ditongos que são realizadas oralmente como monotongos fonológicos, segundo as normas de pronúncia da Língua Inglesa. Para a coleta de dados, foram utilizados um questionário fonético-fonológico com 22 perguntas e uma lista com 31 sentenças para leitura em voz alta, resultando em 1.045 realizações provenientes de 21 informantes de níveis intermediário e avançado em Língua Inglesa. Os principais resultados apontam que a maior parte dos participantes deste estudo realizam os ditongos ortográficos da L2 conforme a norma culta de pronúncia daquela língua. No entanto, detectamos formas foneticamente marcadas e analisamos os aspectos linguísticos a fim de revelar quais podem influenciar mais significativamente nas produções orais dos segmentos em questão.

\section{Palavras-chave:}

Ditongos ortográficos. Realizações orais. Língua Inglesa.

Signum: Estudos da Linguagem, Londrina, v. 22, n. 3, p. 106-128, der. 2019 


\section{Realizações Orais dos Ditongos Ortográficos \\ em Língua Inglesa ${ }^{1}$}

Alexandre Stein; Dircel Aparecida Kailer

\section{INTRODUÇÃo}

A Língua Inglesa, quando comparada às demais línguas, é considerada de fácil aprendizagem por aprendizes falantes de outras línguas, devido à sua relativa simplicidade sintática. No entanto, aspectos como o léxico e a fonologia apresentam certa dificuldade para aqueles que se dispõem a aprendê-la. Em conversa com professores de inglês, e com base em nossa experiência de sala de aula, detectamos que a realização oral dos segmentos vocálicos é um dos aspectos fonético-fonológicos de maior dificuldade para os aprendizes brasileiros.

Diante disso, estabelecemos como objetivo geral deste estudo investigar como monotongos orais, grafados como ditongos, são realizados por aprendizes brasileiros em níveis intermediário e avançado de inglês. Elegemos os ditongos ortográficos para a análise porque, por meio de constatação empírica, hipotetizamos que aprendizes adolescentes e adultos, em geral, são expostos às palavras escritas antes ou concomitantemente ao conhecimento de sua pronúncia, e isso pode influenciar na realização oral desses segmentos.

Em inglês, há duas formas de realização oral das palavras grafadas com ditongos. A primeira, e de menor ocorrência, engloba ditongos ortográficos realizados oralmente como dois fonemas distintos - caso de height e painter, realizados [hart] ['peintor] ${ }^{2}$ respectivamente. A segunda, e de maior ocorrência na língua, apresenta ditongos ortográficos realizados oralmente com um único fonema, como é o caso de ceiling, said e because, realizados ['si:ly], [sed] e [bI'kpz], respectivamente $(\mathrm{ROACH}, 2009$; CELCE-MURCIA; BRINTON; GOODWIN, 2010).

Considerando as referidas possibilidades de realizações orais dos ditongos ortográficos em Língua Inglesa, os objetivos específicos deste estudo são: i) verificar se os fatores linguísticos - como tipos de ditongos ortográficos, posição do ditongo ortográfico nas palavras-alvo e tonicidade da sílaba-alvo, entre outros - têm influência na

\footnotetext{
${ }_{1}$ Este artigo foi redigido com base em uma pesquisa mais abrangente que resultou em uma tese de doutorado em Estudos da Linguagem.

${ }^{2}$ Neste estudo, a retroflexa é representada pelo símbolo /r/ conforme Roach (2009) e Celce-Murcia, Brinton e Goodwin (2010).
} 
realização dos ditongos ortográficos; ii) verificar se as realizações orais dos ditongos ortográficos diferem conforme o contexto de produção, ou seja, conforme o grau de monitoramento (questionário fonético-fonológico e sentenças para leitura, em voz alta).

No intuito de atingirmos os objetivos propostos, realizamos uma coleta de dados utilizando um questionário fonético-fonológico com 22 perguntas e uma lista com 31 sentenças, contento 41 palavras-alvo, para leitura em voz alta. Os dados obtidos foram transcritos, codificados e rodados no programa computacional Goldvarb $X$, que nos forneceu os resultados em percentual.

Para conduzirmos as análises, lançamos mão de diferentes aportes teóricos, como as teorias sobre Aquisição de Segunda Língua, os princípios da Consciência Fonológica, da Variação Linguística em L2 e os pressupostos de interlíngua (ECKMAN, 1981; ELLIS, 1986, 1994; FRASER, 2000; MORI, 2000; KEYS, 2001; TREHEARNE, 2003; BAYLEY, 2005; ZIMMER; ALVES, 2006; ALVES, 2012a; ARCHIBALD, 2018). Estes aportes serão apresentados brevemente, nas próximas seções, por conta da extensão deste artigo.

\section{Aquisição de Segunda Língua e Variação Linguística}

Os estudos que tomaram como base análises que englobam a Aquisição de Segunda Língua (ASL) e a Sociolinguística Variacionista (LABOV, 2008) deram origem à então chamada Variação em Segunda Língua (ELLIS, 1986, 1994). Alguns pesquisadores - como Beebe (1977); Selinker e Douglas (1985); Tarone (1985) e Ellis (1987) acreditavam que essa variação era causada por alguns fatores específicos, por exemplo, a etnia do aprendiz, o tempo de elaboração que esse aprendiz tinha para produzir a língua-alvo ou mesmo o tópico discutido. No entanto, Bayley (2005) defende que, na verdade, a variação de dado aspecto numa língua estrangeira pode ser o resultado de um conjunto de fatores, o que ele chama de "Princípio das Múltiplas Causas". Para ele, "a questão para o pesquisador não é qual fator está associado à variação, mas qual é a força que diferentes fatores, associados à variação, exercem sobre esta" (p. 3). 3,4 Ainda segundo o autor, "tentar explicar a variação na interlíngua ${ }^{[5]}$ como resultado de um único fator é ignorar as complexidades da Aquisição de Segunda Língua". ${ }^{6}$

Com base nessas afirmações, Bayley (2005) estabelece quatro contribuições importantes da Linguística Variacionista para as pesquisas em ASL, apresentadas no Quadro 1, a seguir:

\footnotetext{
${ }^{3}$ The question for the researcher is thus not which single factor is associated with variation, but what the relative strength of the different factors associated with variation is.

${ }^{4}$ Todas as traduções são nossas. Neste artigo, apresentamos a tradução no corpo do texto e o original em nota de rodapé.

${ }^{5}$ As teorias de interlíngua serão apresentadas na próxima seção.

${ }^{6}$ To attempt to explain interlanguage variation as a result of a single factor is to ignore the complexities of SLA.
} 
Quadro 1 - Contribuições da Linguística Variacionista para pesquisas

\begin{tabular}{|c|l|}
\hline 1) & $\begin{array}{l}\text { A Linguística Variacionista oferece um caminho claro para se estudar os efeitos da transferência } \\
\text { nas línguas. }\end{array}$ \\
\hline 2) & $\begin{array}{l}\text { As análises detalhadas de formas variantes produzidas pela sociolinguística quantitativa } \\
\text { em comunidades de fala mundo afora nos fornece uma visão muito mais realista de como a } \\
\text { língua-alvo funciona do que as gramáticas tradicionais. }\end{array}$ \\
\hline 3$)$ & $\begin{array}{l}\text { As análises variacionistas nos fornecem um meio de testar se a ASL está envolvida num processo } \\
\text { de reestruturação repetida ou se ela progride gradualmente ao longo de um continuum } \\
\text { multidimensional. }\end{array}$ \\
\hline 4$)$ & $\begin{array}{l}\text { Como as pesquisas variacionistas são vistas como uma nova vertente de pesquisas que examinam } \\
\text { a aquisição dos padrões de variabilidade de uma língua-alvo, elas nos oferecem a compreensão } \\
\text { do processo pelo qual os aprendizes avançam ou não, indo muito além do estilo formal que } \\
\text { caracteriza a maioria das instruções de sala de aula. }\end{array}$ \\
\hline
\end{tabular}

Fonte: Elaboração dos autores com base em Bayley (2005, p. 3-4).

Como podemos verificar no Quadro 1, na primeira contribuição apresentada, vemos a expressão 'transferência em línguas', amplamente usado na ASL e que representa uma noção importante na descrição das variações encontrada na língua-alvo. Ela se refere à influência de propriedades da primeira língua na produção da segunda língua de um indivíduo, o que acarreta desvios de pronúncia e formas faladas e escritas que destoam da norma culta da L2 (ARCHIBALD, 2018). No entanto, Bayley (2005, p. 4) afirma que nem sempre o uso inadequado de um traço na língua-alvo (L2) é resultado de transferência da língua materna (L1). Esse uso inadequado pode ser resultado de uma "versão idealizada" daquilo que o aprendiz julga estar certo na L2.

Com relação à segunda contribuição dos estudos variacionistas para aquisição de segunda língua e suas variações, Bayley (2005) afirma que tais variações podem ser provenientes do contato do aprendiz com falantes de variedades da língua-alvo. Como exemplo, o autor cita o caso de imigrantes porto-riquenhos vivendo em Nova York adquirirem traços linguísticos do Inglês Vernacular Afro-Americano (IVAA), por terem muito contato com essa comunidade de fala. Ou seja, aquilo que aparentemente se configura como uma falha na aquisição de uma segunda língua pode, sob a perspectiva da Sociolinguística Variacionista, representar uma habilidade do aprendiz em captar e/ou assimilar as especificidades da língua-alvo em sua modalidade vernacular.

\footnotetext{
7 1) Variationist Linguistics offers a clear way to study the effects of language transfer. 2) The detailed analyses of variable forms produced by quantitative sociolinguists in speech communities around the world provide a much more realistic view of how target language function than do traditional grammars. 3) Variationist analysis provides a means of testing whether SLA involves a process of repeated restructuring or whether it proceeds gradually along a multi-dimensional continuum. 4) [As Variationist studies are seen as] a new strand of research that examines the acquisition of target language patterns of variability, they offer insights into the process by which learners may move (or not) beyond the formal style that characterizes most classroom instructions.
} 
No que se refere à terceira e à quarta contribuições, Bayley (2005, p. 5) discorre que "limitações linguísticas operam da mesma forma para todos os falantes" de uma mesma língua no processo de aquisição de uma segunda. Isto é, estudos comprovam que as variações na L2 cometidas por um indivíduo de determinada língua vão, provavelmente, replicar-se em todos os falantes daquela L1, principalmente no que se refere à estrutura gramatical da L2. No entanto, essas variações vão diferir de um indivíduo para outro, conforme o grau de proficiência alcançado na L2.

\section{INTERLÍNGUA}

Segundo Keys (2001, p. 157), “o termo 'interlíngua' (IL) surgiu do trabalho de Selinker (1972) e referia-se às estruturas gramaticais provisórias desenvolvidas por aprendizes de segunda língua durante o processo de aquisição da língua-alvo".

Atualmente, esse termo tem sido amplamente usado para designar "um ponto variável num continum entre a língua nativa (LN) e a língua-alvo (LA)" (KEYS, 2001, p. 157) em quaisquer aspectos do ensino e da aprendizagem de uma segunda língua, ou seja, nos níveis gramatical, lexical, semântico e fonético-fonológico.

Ainda segundo o autor,

O termo 'interlíngua' pode ser aplicado em dois casos: no âmbito sincrônico, ou seja, o estado em que se encontra o sistema [linguístico] de um aprendiz num dado momento, e no âmbito diacrônico, que se refere ao desenvolvimento de um sistema [inguístico] intermediário ao longo do tempo (p. 157). ${ }^{8}$

Para Keys (p. 157), "a ideia de que o desenvolvimento" linguístico de um aprendiz de segunda língua "é linear e progressivo é enganosa", uma vez que essa "interlíngua se desenvolve ao longo do tempo na medida em que o aprendiz recebe input da língua-alvo e a modifica de acordo com esse input".

Esse conhecimento sobre interlíngua é extremamente importante para entendermos por que aprendizes de dada língua cometem determinados desvios na língua-alvo em determinados estágios da aprendizagem desta língua. Além disso, oferece subsídios para que professores e elaboradores de materiais didáticos possam antecipá-los ou propor recursos para saná-los, ou ao menos chamar a atenção para os aspectos que levam os aprendizes a cometerem esses desvios.

\section{ConsciênCIA FonOlÓGica}

Consciência fonético-fonológica, de modo geral, é definida como a habilidade

\footnotetext{
8 The term 'interlanguage' can be seen to apply in two cases: synchronic, or the state of a learner's [linguistic] system at a given point in time; and diachronic, meaning the development of intermediate systems over time.
} 
de reconhecer e manipular os sons da língua falada. Em outras palavras, é entender que a língua é formada por palavras, que palavras são formadas por sílabas e que estas, por sua vez, são compostas de unidades mínimas de som, os fonemas (TREHEARNE, 2003). Essa abordagem é bastante conhecida e utilizada na fase de alfabetização, ou seja, está associada ao desenvolvimento da leitura e da escrita e do estabelecimento da relação letra/som num estágio inicial de aprendizado formal da língua materna.

Contudo, impulsionamos, no presente estudo, uma (re)apropriação da consciência fonológica no trabalho com as habilidades orais (produção e compreensão) no ensino e aprendizagem de Língua Inglesa como L2, privilegiando o ensino explícito de representações fonéticas dos sons dessa língua. Essa perspectiva de apropriação da consciência fonológica na L2 encontra respaldo nos estudos de Fraser (2000), Mori (2000) e Alves (2012a). Para Fraser (2000, p. 182), "prover os alunos com um modelo auditivo não é por si só suficiente para ajudá-los a melhorar sua pronúncia".

Alves (2012b), ancorado em Chard e Dickson (1999), define consciência fonológica como "um entendimento deliberado acerca dos diversos modos como a língua oral pode ser dividida em componentes menores (frases, palavras, sílabas e sons [fonemas]) e então manipulada" (p. 31). A partir deste entendimento, o falante de uma língua deveria ser "capaz de falar sobre seu próprio código, expondo suas descobertas e inferências a respeito de como os sons se combinam, quais as combinações de sons possíveis, e também as que não ocorrem em sua língua" (p. 31).

O autor destaca que existe um "continum dos níveis de consciência fonológica", os quais, segundo Chard e Dickson (1999), são desenvolvidos ao longo do amadurecimento intelectual do indivíduo. Nesse continuum, encontramos os seguintes níveis: sensibilidade às rimas de palavras, consciência da sílaba, consciência das unidades intrassilábicas e consciência fonêmica, necessariamente nessa ordem. O último nível, a consciência fonêmica, é considerado o mais sofisticado e complexo de todos, pois "implica saber reconhecer que as palavras são constituídas de sons de caráter distintivo, envolvendo a capacidade de manipulação que inclui segmentar, unir e modificar tais sons [...] para a criação de novas palavras" (ALVES, 2012b, p. 33). Diante do exposto, Alves atribui duas palavras-chave à consciência fonológica: "reflexão e manipulação" (p. 32).

Ainda sobre o último nível da consciência fonológica, o fonêmico, diz-se como sendo o de maior complexidade, pois sugere que o indivíduo tenha a capacidade de, diante de sons como /p/ e /b/, saber que esses são distintivos e que acarretarão mudança de sentido da palavra caso substitua-se um pelo outro (ex. pote e bote). Da mesma forma, um indivíduo fonemicamente consciente deve ser capaz de perceber que os sons /t/ e / $\mathrm{t}$ / são, ao menos em português, alofones, ou seja, não causarão mudança de sentido em palavras como tia ( [ t $\left.\int i a\right]$ ou [tia]) (ALVES, 2012b, p. 39). Já em inglês, os referidos sons configuram-se como fonemas, pois têm valor distintivo; por exemplo, se o vocábulo 'tore' [to:] for realizado oralmente como [t $\int \Im:$ : (chore) teremos, então, duas lexias totalmente diferentes: 'rasgado' e 'tarefa doméstica', respectivamente. Diante disso, 
podemos perceber a importância do desenvolvimento da consciência fonológica tanto para a aquisição de língua materna quanto para a de uma segunda língua.

Com base no exposto até aqui, podemos supor que um aprendiz de L2, já alfabetizado em sua L1, é capaz de transferir suas habilidades de manipulação e reflexão da L1 para a L2. No entanto, para Alves (2012a, p. 171), isso "não é verdade". Segundo o autor, por mais que esse aprendiz seja fonologicamente consciente sobre sua L1, certamente não terá o mesmo nível de consciência dos sons da língua em aquisição. Nesse sentido, ele afirma que "as diferenças entre ambos os sistemas sonoros precisam ser notadas pelo aprendiz, para que elas então possam ser manipuladas" (p. 171).

A partir disso, podemos afirmar que é de suma importância o trabalho do professor de L2 no despertar da consciência fonológica de seus aprendizes, já que muitos aspectos, principalmente no nível fonêmico, podem não ser tão evidentes para esses aprendizes quanto se imagina.

\section{O Sistema Vocálico da Língua Inglesa}

De acordo com Ladefoged (2005), existem aproximadamente 200 sons vocálicos nas línguas do mundo. No Quadro 2, a seguir, apresentamos os sons vocálicos da Língua Inglesa.

Quadro 2 - Sistema Vocálico da Língua Inglesa ${ }^{9}$

\begin{tabular}{|c|c|c|c|}
\hline \multicolumn{2}{|c|}{ Inglês Britânico } & \multicolumn{2}{|c|}{ Inglês Norte-Americano } \\
\hline $\begin{array}{c}\text { Monotongos Orais } \\
\text { (12) }\end{array}$ & $\begin{array}{c}\text { Ditongos Orais } \\
\text { (8) }\end{array}$ & $\begin{array}{c}\text { Monotongos Orais } \\
\text { (10) }\end{array}$ & $\begin{array}{c}\text { Ditongos Orais } \\
\text { (5) }\end{array}$ \\
\hline 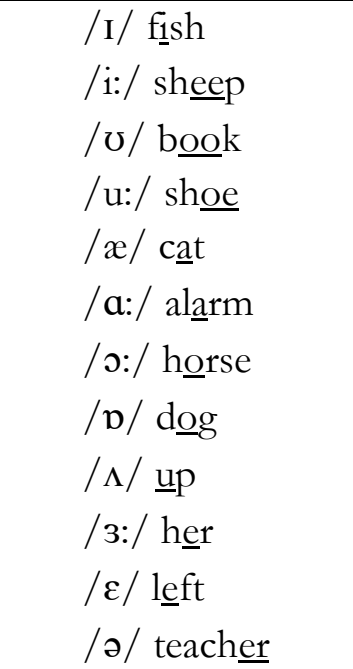 & 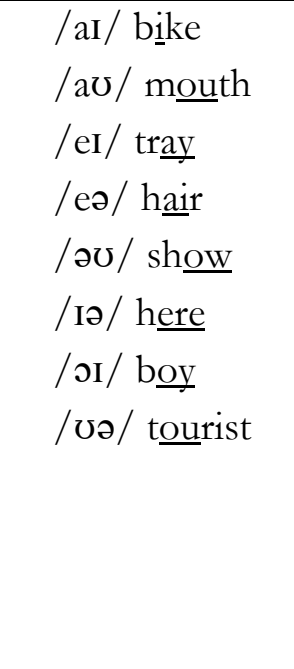 & $\begin{array}{l}\text { /I/ fish } \\
\text { /i/ sheep } \\
/ \mho / \text { book } \\
/ u / \text { shoe } \\
/ x / \text { cat } \\
\text { /a/ alarm } \\
\text { /o/ horse } \\
/ \Lambda / \underline{u} \\
/ \varepsilon / \text { left } \\
/ ə / \text { teacher }\end{array}$ & $\begin{array}{l}\text { /aI/ bike } \\
\text { /av/ mouth } \\
\text { /eI/ tray } \\
\text { /ov/ show } \\
\text { /or/ boy }\end{array}$ \\
\hline
\end{tabular}

Fonte: Elaboração dos autores com base em Roach (2009) e Celce-Murcia, Brinton e Goodwin (2010).

9 Para este artigo, adotamos o padrão de transcrição apresentado pelos dicionários Cambridge English Dictionary e The Oxford English Dictionary e pelos autores Davenport e Hannahs (2005); Roach (2009); Ashton e Shephard (2012), por estarem em maior conformidade com o IPA (International Phonetic Alphabet). 
Constatamos, pelo Quadro 2, que, em inglês norte-americano, há 15 sons vocálicos, sendo 10 vogais orais $-/ \mathrm{I} /, / \mathrm{v} /, / \mathfrak{x} /, / \mathrm{p} /, / \mathrm{\jmath} /, / \Lambda /, / \mathrm{i} /, / \mathrm{u} /, / \mathrm{a} /, / \mathrm{o} /$ - e 5 ditongos orais - /arI/, /eI /, /oI/, /au /, /oun/ (CELCE-MURCIA; BRINTON; GOODWIN, 2010).

Já em inglês britânico temos 20 sons vocálicos, sendo: 7 monotongos simples

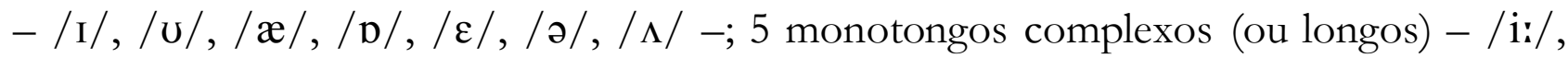
/u:/, /a:/, /o:/, /3:/ -; e 8 ditongos orais - /aI/, /av/, /ıə/, /eI/, /eə/, /əv/, /əI/, /vo/ (ROACH, 2009). Os 8 ditongos do inglês britânico dividem-se em: cinco

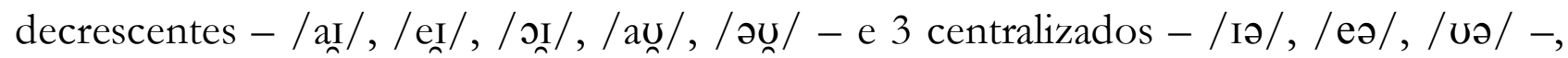
lembrando que os 3 ditongos centralizados só ocorrem no inglês britânico em algumas palavras, como hear [hı'], hair [heər'], tourist ['tuərıst] (CRISTÓFARO-SILVA, 2012).

Celce-Murcia, Brinton e Goodwin (2010, p. 114) apregoam que os fatores a serem levados em consideração quando estudamos os sons vocálicos são:

1) o grau ao qual uma vogal é articulada quando acompanhada de um glide; 2) o lugar de articulação da vogal dentro da cavidade oral (alta, média, baixa e anterior, central, posterior);

3) a posição dos lábios durante a sua articulação (não arredondado, neutro, arredondado); e 4) a qualidade vocálica (tenso e frouxo). ${ }^{10}$

Esses aspectos deveriam fazer parte da instrução de aprendizes de inglês como segunda língua ou língua estrangeira, no intuito de auxiliá-los no processo da aquisição da fonologia dessa língua.

\section{Estudos Sobre a Produção de Vogais e Ditongos em Inglês como L2}

Nesta seção, apresentamos alguns estudos que investigam a produção de ditongos fonológicos da Língua Inglesa. Os referidos estudos retratam o processo de aquisição da Língua Inglesa por aprendizes de outras línguas.

Balas (2009) investiga as possíveis mudanças na pronúncia dos ditongos centralizados da Língua Inglesa em dados obtidos por meio da leitura de sentenças realizadas por nove poloneses de nível avançado de inglês, com idades entre 19 e 25 anos, e um falante nativo de inglês britânico. Segundo a autora, na Língua Polonesa não existem ditongos, apenas sequências de vogais acompanhadas de glides que se assemelham aos ditongos crescentes da Língua Inglesa, mas não aos ditongos centralizados.

Ancorada no aporte teórico da 'Fonologia Natural' ou 'Linguística Natural', 11 ela

\footnotetext{
10 1) The degree to which the vowel is articulated with an accompanying glide; 2) The vowel's relative place of articulation within the oral cavity (bigh versus mid versus low; front versus central versus back); 3) The position of the lips during articulation (spread versus neutral versus rounded); and 4) Vowel quality: tense versus lax.

${ }^{11}$ Cf. Dressler (1984, 1985, 1996, 1999); Donegan (1985, 1993, 2001); Dziubalska-Kołaczyk (1990, 1995, 2001, 2002a, 2002b); Riitt (2001), todos citados por Balas (2009).
} 
verifica que os ditongos produzidos por aprendizes poloneses de inglês encontram-se numa categoria que ela chama de Vowel Space Repopulation, ou seja, os sons produzidos pelos poloneses não são explicados por meio dos conceitos de transferência ou interferência. A autora pressupõe que as realizações ditongais desse grupo de aprendizes estejam situadas no sistema fonológico da interlíngua de L2.

Assim, ela conclui que não é possível fazer nenhuma afirmação definitiva sobre a aquisição da altura vocálica por poloneses falantes de inglês. Com relação ao ditongo fonológico / Iə/, os valores de $\mathrm{F}^{12}$ demonstraram que a produção do falante nativo de Língua Inglesa foi mais alta na primeira parte do ditongo do que na produção dos poloneses. A respeito do ditongo fonológico / $\mathrm{U \curvearrowright} /$, a primeira parte deste segmento foi mais baixa na produção dos poloneses falantes de inglês do que na do falante nativo. Quanto ao ditongo /eə/, foi observado o abaixamento dos valores de F1 na primeira parte do segmento por falantes de polonês aprendizes de inglês.

Mousa (2015) também estuda a produção dos ditongos fonológicos da Língua Inglesa como L2. Sua pesquisa é realizada sob a premissa de que "anos de investigação têm revelado que a linguagem infantil, o aprendizado de uma segunda língua ou língua estrangeira e as línguas crioulas ou de contato (pidgin) estão, mais ou menos, relacionadas em termos de processamento" (p. 1). ${ }^{13}$ Para confirmar tal premissa, o autor compara o processo de aquisição dos ditongos centralizados /ov/ e / eI/, em palavras como home e lane, por aprendizes árabes com o processo de crioulização ${ }^{14}$ de dois falantes do Crioulo ${ }^{15}$ Jamaicano.

Como acontece no polonês, na Língua Árabe, de acordo com Mousa (2015, p. 2), também não há ditongos fonológicos e as "combinações vocálicas parecidas com ditongos", como /aw/ e /aj/, são realizadas como /o:/ e /e:/, respectivamente. Afirma, ainda, que /aw/ e /aj/ não são considerados ditongos, pois /w/ e / j/ têm um status consonantal.

Quanto ao Crioulo Jamaicano, Mousa (2015) afirma existirem os ditongos /ai/, /ou/, /ie/ e /uo/, que se aproximariam dos sons vocálicos de palavras em inglês como mice, cow, cane e goat. No entanto, afirma que "o Crioulo Jamaicano foi afetado por uma tendência de redução vocálica a qual passou a maioria das línguas advindas de pidgins"

\footnotetext{
${ }^{12}$ Balas (2009), após submeter os dados coletados ao programa de análise acústica Praat (cf. BOERSMA; WEENINK, 2008 [1992], em Balas), usou os índices dos formantes F1, F2 e F3 para comparar os ditongos centralizados da Língua Inglesa realizados por um falante nativo desta língua e os realizados pelos aprendizes poloneses falantes de inglês.

${ }^{13}$ Years of investigation have revealed that child language, second/foreign language learning, and pidgin and creole languages are, more or less, related in terms of processing.

14 "Processo ao longo do qual um pidgin deixa de ser uma língua de contato para tornar-se a língua materna de uma comunidade de falantes" (PIDGIN, 2019).

${ }^{15}$ Acepção 6: "Dialeto falado pelos habitantes de antigas colônias européias (sic) na América" (CRIOULO, 2019).
} 
(p. 3). Portanto, vocábulos como face / feIs/ e goat / gout/ são frequentemente realizados como /fe:s/ ou /fies/ e /go:t/ ou /guot/ por falantes do Crioulo Jamaicano.

Os resultados de sua pesquisa apontam que, em todos os casos, os aprendizes árabes produziram /o:/ em vez de /ov/ em palavras como home, hope, coat, rope, e /e:/ para / eI/ em vocábulos como rain, lane, train. Esses achados poderiam levar pesquisadores a acreditar que tais 'desvios' foram produzidos por transferência da L1; no entanto, coincidentemente, os informantes jamaicanos também optaram pelos referidos monotongos - /o:/, /e:/ - na produção oral dos ditongos citados.

Mousa (2015) conclui que, se falantes de origens tão diferentes optaram pela mesma produção dos segmentos em questão (os ditongos fonológicos centralizados), então, a hipótese de transferência não se sustenta. Como embasamento para essa hipótese, o autor afirma que a referida produção monotongada, além de ser encontrada na produção de informantes de diferentes origens étnicas que estão aprendendo uma L2, também é encontrada na produção oral de crianças de diferentes etnias em fase de aquisição de suas línguas maternas. Portanto, essas crianças não teriam a influência de outra língua na realização dos ditongos em sua L1. Por outro lado, a produção de vogais longas demonstra que os participantes da pesquisa realizada têm consciência de que as vogais contidas nos vocábulos não são simples, mas complexas.

Na seção seguinte, discorremos sobre a realização dos ditongos ortográficos nas palavras-alvo selecionadas para este estudo.

\section{As Realizações Orais dos Ditongos Ortográficos em Língua Inglesa}

Nesta seção, focalizamos o funcionamento da Língua Inglesa, no intuito de entendermos por que brasileiros falantes de inglês realizam alguns ditongos ortográficos de forma desviante, ou seja, em discordância com as normas de pronúncia da Língua Inglesa culta.

Diferentemente do português, no qual, na maioria dos casos, a realização oral de um ditongo ortográfico como monotongo fonológico é interpretada como uma variação linguística da norma culta, em inglês temos duas situações:

- na primeira, nos referimos às palavras grafadas com ditongos que, se pronunciadas como ditongos fonológicos, ${ }^{16}$ serão ininteligíveis - por exemplo: juice, caution, bought (suco, cuidado, comprou) - e, portanto, precisam, necessariamente, ser realizadas com monotongos fonológicos - [dzu:s], ['kə:Sən], [bə:t], respectivamente;

- na segunda, temos palavras grafadas com ditongos que são realizadas como dois fonemas distintos - por exemplo, painter ['peintər], sound [saund] e approach [ə'proutS]

\footnotetext{
${ }^{16}$ Embora saibamos que, em inglês, existem algumas palavras que, mesmo grafadas com ditongos, são pronunciadas como monotongos, nosso intuito é apontar que brasileiros aprendizes dessa língua devem ter consciência sobre esse aspecto.
} 
(pintor, som e abordagem, respectivamente) (ASHTON; SHEPHERD, 2012; SMITH; MARGOLIS, 2012).

Essa alternância entre a realização oral de ditongos ortográficos, ora como monotongos, ora como ditongos fonológicos, muitas vezes causa dificuldade de aprendizagem para aqueles que se dispõem a aprender inglês. Isso acontece principalmente quando o contato com a língua ocorre a partir da adolescência ou na fase adulta, pois, geralmente, esses aprendizes são expostos à forma escrita das palavras antes ou ao mesmo tempo em que são apresentados às pronúncias delas, o que, por influência da escrita, pode levá-los a fazer uma associação equivocada entre grafia e realização oral.

É a partir dessa premissa que investigamos como brasileiros aprendizes de Língua Inglesa, em níveis intermediário ou avançado, realizam os ditongos elencados no Quadro 3.

Quadro 3 - Vocábulos em inglês contendo ditongos ortográficos e suas realizações conforme a norma culta da língua-alvo

\begin{tabular}{|c|c|c|c|c|c|}
\hline $\mathbf{N}^{\mathbf{0}}$ & $\begin{array}{c}\text { Ditongos } \\
\text { ortográficos }\end{array}$ & \multicolumn{2}{|c|}{$\begin{array}{l}\text { Realizados como monotongos } \\
\text { fonológicos na língua-alvo }\end{array}$} & \multicolumn{2}{|c|}{$\begin{array}{l}\text { Realizados como ditongos } \\
\text { fonológicos na língua-alvo }\end{array}$} \\
\hline 01 & $<\mathrm{ai}>$ & $\begin{array}{l}\text { against } \\
\text { said }\end{array}$ & $\begin{array}{l}\text { [ə'g genst] } \\
{[\mathrm{s} \varepsilon \mathrm{d}]}\end{array}$ & $\begin{array}{l}\text { painter } \\
\text { trained }\end{array}$ & $\begin{array}{l}\text { ['peIntor] } \\
\text { [treInd] }\end{array}$ \\
\hline 02 & $<\mathrm{au}>$ & $\begin{array}{l}\text { aunt } \\
\text { author } \\
\text { because } \\
\text { caught } \\
\text { caution } \\
\text { sauce } \\
\text { taught }\end{array}$ & 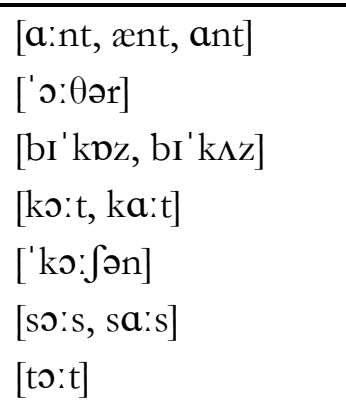 & & \\
\hline 03 & $<$ ea $>$ & $\begin{array}{l}\text { deal } \\
\text { death } \\
\text { early } \\
\text { earth } \\
\text { heard } \\
\text { heart } \\
\text { heavy } \\
\text { learned } \\
\text { peace } \\
\text { sea }\end{array}$ & $\begin{array}{l}\text { [di:l] } \\
\text { [d } \varepsilon \theta] \\
{[\text { '3:(r)li] }} \\
{[3:(r) \theta]} \\
\text { [h3:(r)d] } \\
\text { [ha:(r)t] } \\
\text { ['hevi] } \\
\text { [l3:(r)nd] } \\
\text { [pi:s] } \\
\text { [si:] }\end{array}$ & $\begin{array}{l}\text { hear } \\
\text { idea }\end{array}$ & $\begin{array}{l}\text { [hIə (r)] } \\
\text { [aI'diə] }\end{array}$ \\
\hline 04 & $<$ ee $>$ & $\begin{array}{l}\text { agree } \\
\text { fee } \\
\text { green } \\
\text { need } \\
\text { speed }\end{array}$ & $\begin{array}{l}\text { [ə'grii:] } \\
\text { [fi:] } \\
\text { [gri:n] } \\
\text { [ni:d] } \\
\text { [spi:d] }\end{array}$ & & \\
\hline
\end{tabular}




\begin{tabular}{|c|c|c|c|c|c|}
\hline \multirow{2}{*}{$\begin{array}{l}\mathbf{N}^{\mathbf{0}} \\
05\end{array}$} & \multirow{2}{*}{\begin{tabular}{l}
\multicolumn{1}{c}{$\begin{array}{c}\text { Ditongos } \\
\text { ortográficos }\end{array}$} \\
$<\mathrm{ei}>$
\end{tabular}} & \multicolumn{2}{|c|}{$\begin{array}{l}\text { Realizados como monotongos } \\
\text { fonológicos na língua-alvo }\end{array}$} & \multicolumn{2}{|c|}{$\begin{array}{l}\text { Realizados como ditongos } \\
\text { fonológicos na língua-alvo }\end{array}$} \\
\hline & & $\begin{array}{l}\text { ceiling } \\
\text { receive }\end{array}$ & $\begin{array}{l}\text { ['si:lin] } \\
\text { [rI'si:v] }\end{array}$ & & \\
\hline 06 & $<\mathrm{eo}>$ & people & ['pi:p(ə)l] & & \\
\hline 07 & $<\mathrm{ie}>$ & $\begin{array}{l}\text { ancient } \\
\text { believe } \\
\text { cookie } \\
\text { grieve } \\
\text { smoothie }\end{array}$ & 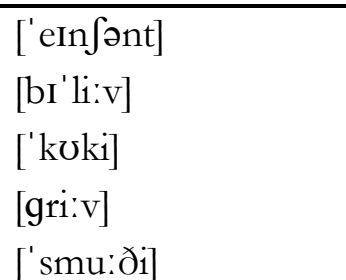 & died & [daId] \\
\hline 08 & $<$ io $>$ & $\begin{array}{l}\text { ambition } \\
\text { education }\end{array}$ & 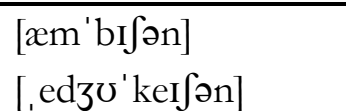 & & \\
\hline 09 & $<_{\mathrm{oa}}>$ & & & $\begin{array}{l}\text { approach } \\
\text { boat } \\
\text { goal }\end{array}$ & 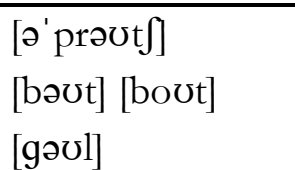 \\
\hline 10 & $<\mathrm{oe}>$ & $\begin{array}{l}\text { canoe } \\
\text { shoe }\end{array}$ & $\begin{array}{l}\text { [kə'nu:] } \\
{\left[\int \mathrm{u}:\right]}\end{array}$ & & \\
\hline 11 & $<\mathrm{oi}>$ & & & $\begin{array}{l}\text { choice } \\
\text { join }\end{array}$ & $\begin{array}{l}\left.\text { [t } \int \text { JIs }\right] \\
\text { [dzoIn] }\end{array}$ \\
\hline 12 & $<_{\mathrm{OOO}}>$ & $\begin{array}{l}\text { blood } \\
\text { choose } \\
\text { root } \\
\text { stood } \\
\text { tattoo } \\
\text { zoo }\end{array}$ & $\begin{array}{l}\text { [blıd] } \\
\text { [tfu:z] } \\
\text { [ru:t] } \\
\text { [stod] } \\
\text { [tæt' u:] } \\
\text { [zu:] }\end{array}$ & & \\
\hline 13 & $<\mathrm{ou}>$ & $\begin{array}{l}\text { bought } \\
\text { could } \\
\text { country } \\
\text { enough } \\
\text { pour } \\
\text { thought }\end{array}$ & 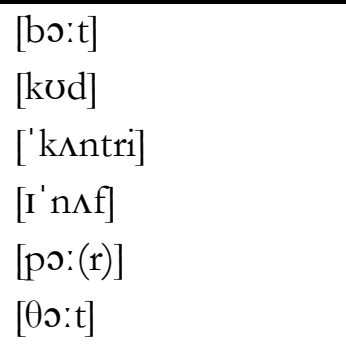 & sound & [saond] \\
\hline 14 & $<$ ue $>$ & glue & [glu:] & & \\
\hline 15 & $<$ ui $>$ & $\begin{array}{l}\text { biscuit } \\
\text { building } \\
\text { juice }\end{array}$ & $\begin{array}{l}\text { ['bis·kit] } \\
\text { ['bildin] } \\
\text { [dzu:s] }\end{array}$ & & \\
\hline
\end{tabular}

Fonte: Elaboração dos autores.

O Quadro 3 apresenta 63 palavras em Língua Inglesa de diversas classes gramaticais, como verbos, substantivos e adjetivos, contendo ditongos ortográficos. Dessas, 52 são realizadas oralmente como monotongos e 11 como ditongos fonológicos (utilizados como distratores). Os referidos vocábulos foram selecionados por conterem ditongos 
na grafia e por sua recorrência em situações de comunicação, conforme nossa experiência empírica como professor de inglês como L2. Como podemos constatar, os 15 ditongos selecionados realizam-se oralmente de diversas formas: por exemplo, o ditongo ortográfico

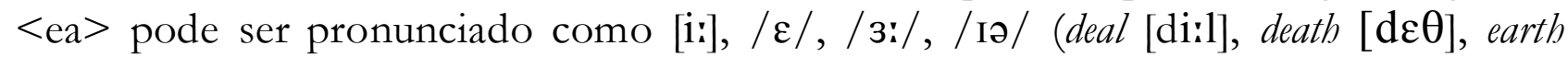
[3:(r) $\theta$ ], idea [aI'diə]). Por isso, em alguns casos, temos diversos vocábulos contendo determinado ditongo, o que justifica a disparidade na ortogonalidade das palavras selecionadas.

\section{Metodologia de Coleta e de Análise dos Dados}

Para este estudo, foram selecionadas 63 palavras em Língua Inglesa contendo encontros vocálicos, conforme apresentado no Quadro 3. Esses vocábulos, de diversas classes gramaticais, foram organizados em uma lista com suas respectivas transcrições fonéticas baseadas em dois dicionários online de Língua Inglesa: o Oxford English Dictionary e o Cambridge Dictionary. ${ }^{17}$ As referidas transcrições contemplam a pronúncia do inglês culto falado no Reino Unido e nos Estados Unidos, respectivamente. Embora existam diversas variedades de pronúncia da Língua Inglesa, usamos apenas essas duas como referência.

Em seguida, para fins de coleta, as palavras foram separadas aleatoriamente em dois grupos. Para as do primeiro grupo, trabalhamos com suas definições, a fim de obtermos as palavras-alvo oralmente. As do segundo grupo foram inseridas em sentenças contextualizadas, para que os participantes as lessem em voz alta, permitindo a obtenção de suas realizações orais. Elaboramos, assim, um questionário semiestruturado com 22 perguntas e uma lista de 31 sentenças, contendo 41 palavras-alvo, para leitura em vOZ alta.

O total de perguntas e sentenças (53) não é igual ao número total de palavras selecionadas (63), pois uma mesma sentença continha duas ou mais palavras-alvo. A disparidade entre o número de palavras do questionário (22) e as das sentenças (41) justifica-se tendo em vista um dos objetivos deste estudo, que é verificar a influência da escrita sobre a pronúncia.

Os 21 participantes são provenientes de uma escola particular de Língua Inglesa de Londrina, no estado do Paraná. Destes, 15 são do sexo feminino e 6 do sexo masculino, com idades entre 14 e 60 anos. Eles foram selecionados, primordialmente, por serem brasileiros estudantes de Língua Inglesa em níveis intermediário ou avançado. Além de assumirmos como parâmetro de proficiência os níveis em que estes aprendizes se encontravam na escola de inglês, aplicamos, ainda, um teste de nivelamento complementar com 50 questões ${ }^{18}$ que nos auxiliou na confirmação do nível de proficiência à época da coleta dos dados.

\footnotetext{
${ }^{17}$ Disponíveis em: <www.oxforddictionaries.com> e <www.dictionary.cambridge.org>.

${ }^{18} \mathrm{O}$ referido teste de nivelamento é de autoria da National Geographic Learning, que faz parte da Cengage Learning Company, e está disponível em <http://www.eltoutcomes.com/>.
} 
Os dados obtidos por meio do questionário e da lista de sentenças para leitura em voz alta foram gravados e posteriormente transcritos, utilizando os símbolos do International Phonetic Alphabet (IPA). Com o intuito de analisarmos os percentuais, submetemos os dados coletados ao programa computacional Goldvarb X (SANKOFF; TAGLIAMONTE; SMITH, 2005). Para isso, os dados foram codificados conforme as seguintes variáveis: 1) a realização oral dos encontros vocálicos como monotongos ou ditongos fonológicos; 2) tipos de ditongos (13 ao todo); 3) posição do ditongo nas palavras-alvo; 4) tonicidade da sílaba-alvo; 5) instrumentos de coleta (questionário ou leitura).

Essas variáveis foram pensadas para dar suporte à análise. Isto é, nosso intuito é verificar se os fatores linguísticos podem influenciar na pronúncia dos ditongos ortográficos em Língua Inglesa. Dados sobre aspectos extralinguísticos não são apresentados neste artigo por questões de limitação de espaço.

\section{Descrição e Análise das Variáveis Linguísticas}

Como ponto de partida para a análise, a Tabela 1 traz as realizações orais por ditongo pesquisado em ordem alfabética. Nela, apresentamos os ditongos ortográficos, os números absolutos e os percentuais de realizações orais como monotongos ou como ditongos fonológicos.

Tabela 1 - Realizações orais dos ditongos ortográficos pelos informantes ${ }^{19}$

\begin{tabular}{cccccc}
\hline $\begin{array}{c}\text { Ditongos } \\
\text { Ortográficos }\end{array}$ & $\begin{array}{c}\text { Total de } \\
\text { realizações }\end{array}$ & $\begin{array}{c}\text { Realizado como } \\
\text { monotongos fonológicos }\end{array}$ & \multicolumn{2}{c}{$\begin{array}{c}\text { Realizado como } \\
\text { ditongos fonológicos }\end{array}$} \\
\hline ai & 42 & 35 & $83,3 \%$ & 7 & $16,7 \%$ \\
au & 143 & 82 & $57,3 \%$ & 61 & $42,7 \%$ \\
ea & 204 & 192 & $94,1 \%$ & 12 & $5,9 \%$ \\
ee & 101 & 101 & $100 \%$ & 0 & $0 \%$ \\
ei & 37 & 26 & $70,3 \%$ & 11 & $29,7 \%$ \\
eo & 21 & 21 & $100 \%$ & 0 & $0 \%$ \\
ie & 99 & 83 & $83,8 \%$ & 16 & $16,2 \%$ \\
io & 33 & 32 & $97 \%$ & 1 & $3 \%$ \\
oe & 41 & 26 & $63,4 \%$ & 15 & $36,6 \%$ \\
oo & 124 & 118 & $95,2 \%$ & 6 & $4,8 \%$ \\
\hline ou & 125 & 99 & $79,2 \%$ & 26 & $20,8 \%$ \\
ue & 14 & 14 & $100 \%$ & 0 & $0 \%$ \\
ui & 61 & 33 & $54,1 \%$ & 28 & $45,9 \%$ \\
\hline TOTAL & $\mathbf{1 0 4 5}$ & $\mathbf{8 6 2}$ & $\mathbf{8 2 , 5 \%}$ & $\mathbf{1 8 3}$ & $\mathbf{1 7 , 5 \%}$ \\
\hline
\end{tabular}

Fonte: Elaboração dos autores.

${ }^{19}$ A Tabela 1 não apresenta os ditongos ortográficos < ao $>$ e < oi > porque os vocábulos selecionados para esta pesquisa contendo esses dois ditongos foram usados somente como distratores. 
Pela Tabela 1, podemos constatar, dentre os 13 ditongos ortográficos da Língua Inglesa selecionados, em quais deles os participantes apresentaram maior dificuldade de realização oral e quais já foram supostamente internalizados por eles. Explicitamos, a partir dessa tabela, as realizações obtidas em relação a cada ditongo.

Para o ditongo ortográfico <ai>, observamos que, entre os $16,7 \%$ de produções realizadas de forma desviante, estão vocábulos como said [sєd] realizado [saId] ou [serd], com incidência de 25,58\%. Acreditamos que tais realizações estejam diretamente ligadas à influência da escrita, já que, nos vocábulos painter ['peıntər] e trained [treınd], utilizados nos instrumentos de coleta como distratores, o ditongo <ai $>$ é realizado oralmente com o ditongo fonológico [er]. Esta hipótese é corroborada no estudo de Das (2014). Para ele, a produção de determinados segmentos por falantes de inglês como L2 pode ser influenciada pela sua ortografia.

No cômputo geral, o ditongo ortográfico $<\mathrm{au}>$ apresenta um índice considerável de realizações ditongadas (42,7\%), ou seja, de forma marcada. Os índices de produção desviante ficam ainda mais expressivos quando analisamos vocábulo a vocábulo. Por exemplo, o referido ditongo <au>, no vocábulo author ['o:Өər], foi realizado pelos participantes como ['autər] ou ['outər] em $88,24 \%$ dos casos. $O$ índice de realizações

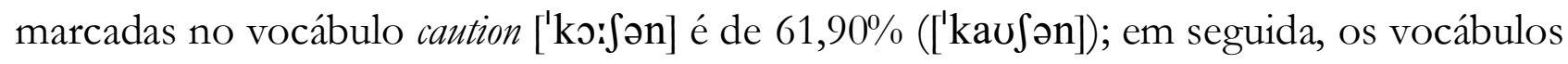
sance [so:s, sa:s], realizado como [sous] em 52,38\% dos casos; aunt [a:nt, ænt], [aunt], com um percentual de 42,86\%; e canght [ko:t, ka:t] realizado como [kavt] ou [kout] em 38,10\% dos casos. Como vimos, para quase $43 \%$ dos aprendizes participantes desta pesquisa, o ditongo $<\mathrm{au}>$ realiza-se como ditongo fonológico, como nos casos apresentados anteriormente ['autər], [aunt], [səus], ['kauən], entre outros. Nossa hipótese para esse alto índice de ocorrências desviantes é a influência da ortografia sobre a oralidade, a transferência de traços da L1 para L2 e a falta de consciência fonológica (cf. ERDENER; BURNHAM, 2005; ZIMMER; ALVES, 2006; ALVES; BARRETO, 2012; ALVES, 2018).

O ditongo ortográfico <ea>, com um total de 204 realizações em vocábulos como deal [di:l], death [de $\theta]$, early ['3:(r)li], earth [3:(r) $\theta]$, heard $[\mathrm{h} 3:(\mathrm{r}) \mathrm{d}]$, heart $[\mathrm{hat}(\mathrm{r}) \mathrm{t}]$, heavy ['hevi], learned [l3:(r)nd], peace [pi:s] e sea [si:], não apresentou um número expressivo de realizações marcadas, apenas $5,9 \%$. Esse índice é bastante surpreendente, já que o ditongo $<$ ea $>$ apresenta pelo menos quatro realizações orais diferentes - /i: $\varepsilon$, 3:, a/ - nos vocábulos selecionados. Acreditamos que a justificativa para o alto índice de realizações em conformidade com a norma culta de pronúncia da Língua Inglesa seja a internalização bem-sucedida dos referidos segmentos pelos participantes da pesquisa.

O mesmo aconteceu com os ditongos ortográficos $<$ ee $>$ e $<$ eo $>$, que não foram realizados de forma desviante pelos participantes em vocábulos como: agree [ə'gri:], fee [fi:], green [gri:n], need [ni:d], speed [spi:d] e people ['pi:p(ə)1].

O ditongo ortográfico $<\mathrm{oe}>$, apesar de presente em apenas duas palavras-alvo (canoe [kə'nu] e shoe [Su:]), apresentou um índice de formas marcadas elevado (36,6\%). Esse índice deve-se principalmente ao vocábulo canoe que, apesar de conter o ditongo <oe> na mesma posição de shoe e ser pronunciado da mesma forma, /u:/, segundo a 
norma culta da Língua Inglesa, foi realizado oralmente pelos participantes como [kæ'noi], [kə'nəu] ou [kə'nou] em 71,43\% dos casos. Sobre esse índice, nossa hipótese recai sobre o fato de o vocábulo canoe ser um cognato na L1 dos participantes.

Outro ditongo ortográfico com índices de realizações desviantes bastante expressivos é o <ui> em vocábulos como biscuit ['bıskıt] e juice [dzu:s]. O vocábulo biscuit foi realizado como ['biskurt] em $80,95 \%$ dos casos, e o vocábulo juice foi realizado como [dzuis] em 50\% dos casos. Novamente, notamos uma possível influência da escrita sobre a fala e um fator de transferência da língua materna para a língua-alvo, já que, em português, o ditongo ortográfico <ui > é realizado oralmente como ditongo fonológico [uI, wI] na maioria dos casos.

Diante do exposto, temos uma descrição dos vocábulos que foram realizados mais frequentemente de forma marcada pelos participantes, tais como said, author, caution, sauce, aunt, canoe, biscuit e juice.

Na seção seguinte, discutimos a posição dos ditongos nas palavras-alvo.

\section{A Realização dos Ditongos Ortográficos Conforme sua Posição na Palavras-Alvo}

O Gráfico 1 retrata os percentuais de realização oral dos ditongos ortográficos da Língua Inglesa conforme suas posições nas palavras-alvo (inicial, medial ou final). Embora o gráfico apresente índices bastante consideráveis de realizações dentro da norma de pronúncia da Língua Inglesa, destacamos os percentuais de realizações marcadas, com o intuito de analisá-los e levantarmos hipóteses que possam justificar tais realizações.

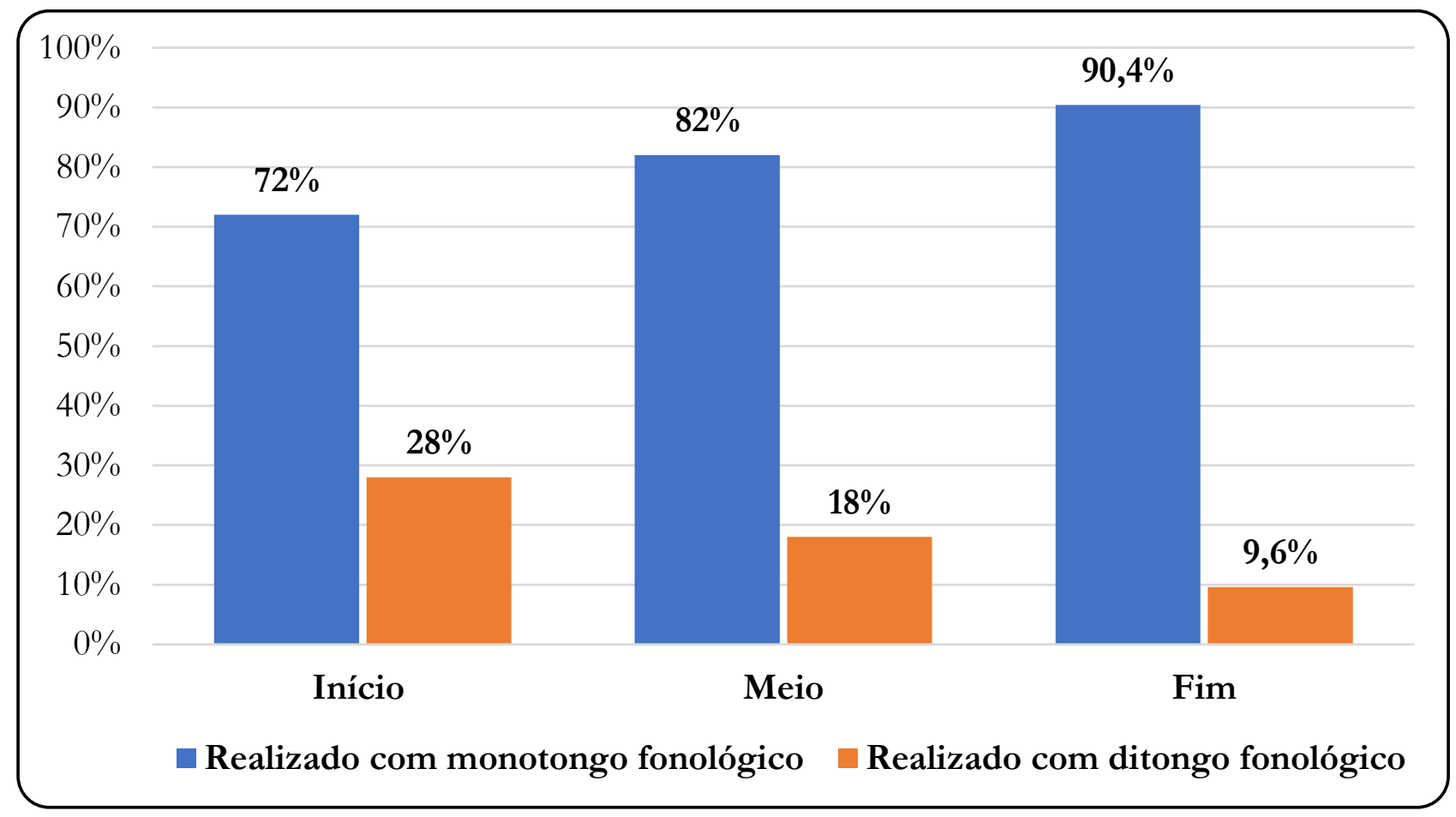

Fonte: Elaboração dos autores.

Gráfico 1 - Realizações dos ditongos ortográficos conforme a posição nas palavras-alvo 
Pelas informações apresentadas no Gráfico 1, podemos constatar que, para este grupo de aprendizes, se o ditongo ortográfico ocorrer na posição inicial do vocábulo, ele tende a ser realizado mais frequentemente de forma ditongada. Exemplos desses vocábulos são author ['ə:Өər] e aunt [a:nt, ænt], realizados ['outər] ou ['autər] e [aunt], respectivamente. Embora, dentre as palavras-alvo, tenhamos poucos exemplares de ditongos ortográficos ocorrendo em posição inicial, eles se mostram bastante relevantes no que diz respeito à incidência de realizações ditongadas. Nossa hipótese para a ocorrência dessas realizações é que, ao recorrerem ao reportório fonológico de sua L1, os aprendizes brasileiros de inglês encontram vocábulos iniciados com ditongos ortográficos quase sempre realizados como ditongos fonológicos, por exemplo, autor, autoridade, auditoria. Por outro lado, a realização do vocábulo early ['3:(r)li] teve 100\% de realizações dentro da norma culta de pronúncia, e earth ['3:(r) $\theta$ ] obteve apenas 9,52\% de realizações como ditongos fonológicos por esse grupo de aprendizes.

Para que tenhamos uma visão mais ampla de como os ditongos ortográficos foram realizados conforme sua posição nas palavras-alvo, apresentamos, na Tabela 2, os vocábulos mais frequentemente realizados de forma desviante.

Tabela 2 - Ditongos ortográficos realizados de forma desviante conforme suas posições nas palavras-alvo

\begin{tabular}{|c|c|c|c|c|}
\hline $\begin{array}{c}\text { Posição dos } \\
\text { ditongos } \\
\text { ortográficos nas } \\
\text { palavras-alvo } \\
\end{array}$ & Vocábulo & $\begin{array}{l}\text { Realização } \\
\text { conforme } \\
\text { língua-alvo }\end{array}$ & $\begin{array}{l}\text { Realização } \\
\text { pelos } \\
\text { participantes }\end{array}$ & $\begin{array}{c}\text { Percentuais } \\
\text { de realizações } \\
\text { desviantes }\end{array}$ \\
\hline \multirow{3}{*}{ Inicial } & aunt & [a:nt, ænt] & [aunt] & $42.86 \%$ \\
\hline & author & ['э:Өər] & ['autər $\sim$ 'outər] & $88.24 \%$ \\
\hline & earth & {$[3:(r) \theta]$} & {$[$ wor $\theta \sim \operatorname{Iər} \theta]$} & $9.52 \%$ \\
\hline \multirow{11}{*}{ Medial } & ancient & ['ein $\left.\int \partial n t\right]$ & 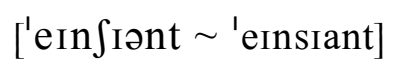 & $82.35 \%$ \\
\hline & bought & [bo:t $]$ & {$[$ bout $]$} & $23.81 \%$ \\
\hline & caught & [ko:t] [ka:t] & {$[$ kaut $\sim$ kout $]$} & $38.10 \%$ \\
\hline & caution & ['ko:Sən] & 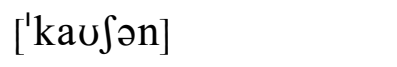 & $61.90 \%$ \\
\hline & ceiling & ['si:lın] & ['seilin] & $41.18 \%$ \\
\hline & country & ['k $\mathrm{\prime} n \mathrm{ntri}]$ & ['kauntri] & $47.62 \%$ \\
\hline & deal & {$[\mathrm{di}: 1]$} & [dial] & $23.81 \%$ \\
\hline & juice & [dzu:s] & [dzuis] & $55 \%$ \\
\hline & said & {$[\mathrm{s} \varepsilon \mathrm{d}]$} & {$[$ said $\sim \operatorname{se}$ Id $]$} & $28.57 \%$ \\
\hline & sauce & {$[\mathrm{s} 0: \mathrm{s}]$} & {$[$ sous $\sim$ saus $]$} & $52.38 \%$ \\
\hline & taught & [to:t $]$ & {$[$ taut $]$} & $19.05 \%$ \\
\hline Final & canoe & [kə'nu:] & [kə'nəu kə'nou $]$ & $71.43 \%$ \\
\hline
\end{tabular}

Fonte: Elaboração dos autores. 
Os vocábulos apresentados na Tabela 2 estão organizados em ordem alfabética. Ao analisarmos a tabela, apesar do número de palavras variar em cada categoria, podemos constatar que as formas marcadas dos ditongos-alvos apresentam índices entre 9,52\% e 88,24\% em posição inicial, 19,05\% e 82,35\% em posição medial e, em posição final, $71,43 \%$ de formas desviantes.

Nas seções seguintes, tecemos algumas considerações sobre a possível influência da tonicidade da sílaba-alvo na realização dos ditongos ortográficos.

\section{Tonicidade da Sílaba-Alvo}

Das 52 palavras-alvo contendo os ditongos ortográficos investigados, $44(84,62 \%)$ apresentam os ditongos-alvo na posição tônica, e $8(15,38 \%)$ na posição átona. Investigamos a tonicidade da sílaba-alvo com o propósito de verificar se esse aspecto tem alguma influência sobre a realização dos ditongos ortográficos pelos participantes em questão. Nos Gráficos 2 e 3, a seguir, apresentamos a ocorrência de realizações como ditongos e monotongos fonológicos, produzidas pelos participantes, nas duas posições.

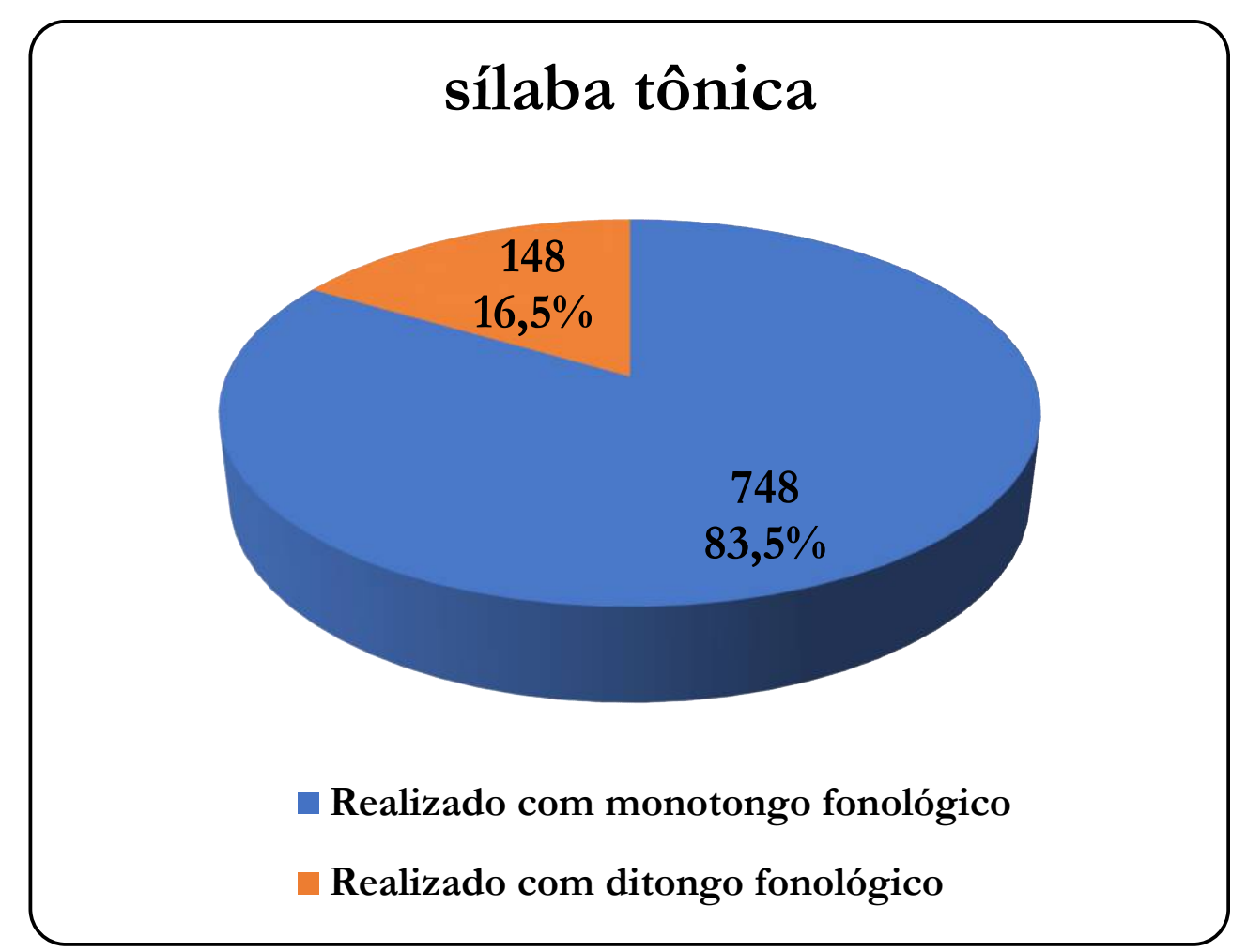

Fonte: Elaboração dos autores.

Gráfico 2 - Realização dos ditongos ortográficos em sílaba tônica 


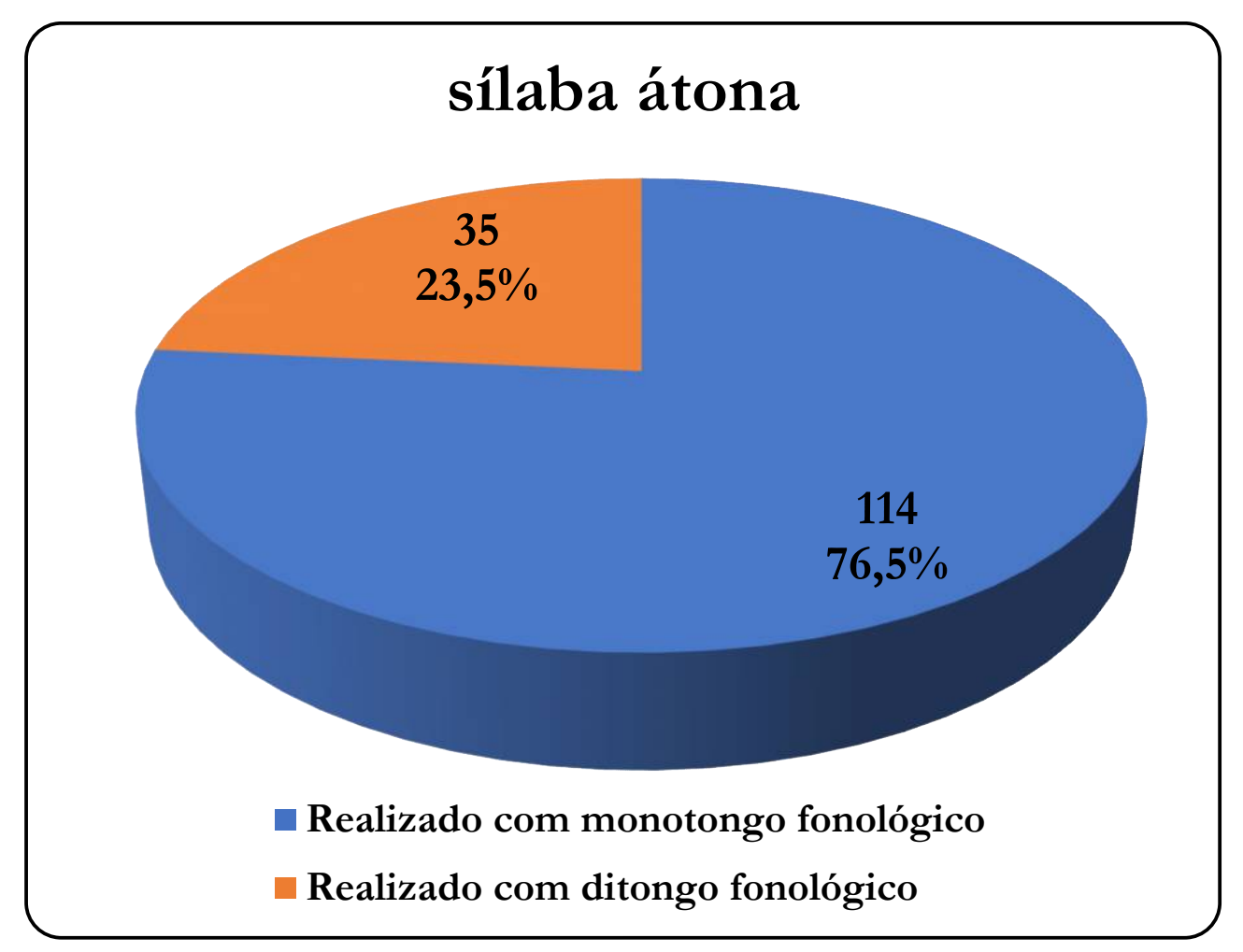

Fonte: Elaboração dos autores.

Gráfico 3 - Realização dos ditongos ortográficos em sílaba átona

Das 1.045 realizações das palavras-alvo coletadas, obtivemos 862 (82,5\%) realizadas como monotongos fonológicos e 183 (17,5\%) como ditongos fonológicos, ou seja, de forma desviante. Como apresentado no Gráfico 2, no cômputo geral, observamos uma incidência menor de ditongos ortográficos realizados como ditongos fonológicos (16,5\%) no grupo em que estes ocorrem em sílaba tônica. Por outro lado, quando o ditongo ortográfico ocorre em sílaba átona, conforme o Gráfico 3, verificamos um índice maior de realizações marcadas (23,5\%).

Quando analisamos os vocábulos separadamente, observamos que nas palavras-alvo em que os ditongos ortográficos ocorrem em sílaba tônica há uma incidência de realizações desviantes bastante significativa. Exemplos desses vocábulos são:

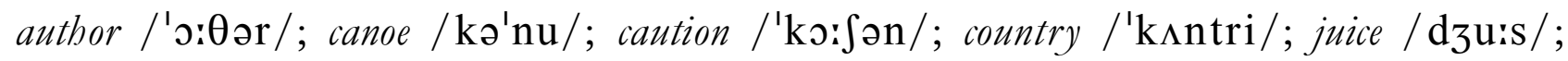

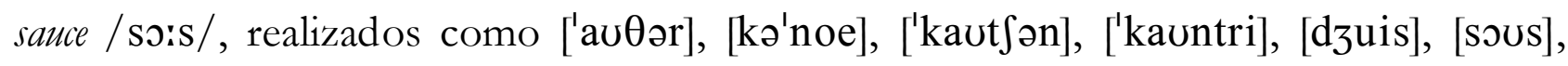
respectivamente.

Com base nesses dados, acreditamos que a realização dos ditongos ortográficos de forma marcada talvez esteja mais relacionada ao tipo de ditongo do que à tonicidade da sílaba-alvo.

\section{Considerações Finais}

Os dados e as análises apresentadas neste artigo levam-nos a refletir sobre as 
variáveis linguísticas que podem influenciar na qualidade das produções orais de lexias em Língua Inglesa contendo ditongos ortográficos. Os dados e as análises apresentadas aqui são provenientes de uma pesquisa de doutorado, logicamente, mais ampla.

As variáveis linguísticas apresentam-se como aspectos importantes para a descrição e a análise dos dados coletados, indicando que alguns ditongos ortográficos têm maior tendência de ser realizados oralmente como ditongos fonológicos do que outros. Nossa hipótese para este resultado é que, no processo de aquisição e produção oral da Língua Inglesa, os aprendizes brasileiros da língua utilizam-se de traços fonológicos da L1 na L2, caracterizando um processo de desenvolvimento da interlíngua dos aprendizes pesquisados.

Contudo, apesar de detectarmos algumas produções orais consideradas desviantes, ou mesmo de difícil entendimento, verificamos que os participantes deste estudo tiveram, em geral, um desempenho bastante satisfatório, com 82,5\% de realizações das palavras-alvo dentro do que se considera de acordo com as normas de pronúncia da Língua Inglesa.

Quanto às questões relacionadas ao ensino e à aprendizagem da pronúncia da Língua Inglesa, acreditamos que este estudo pode contribuir para o entendimento de como se dá a realização oral dos ditongos ortográficos da Língua Inglesa por aprendizes brasileiros e, assim, motivar professores de inglês a utilizarem a instrução explícita de pronúncia como ferramenta para um aumento da consciência fonético-fonológica desses aprendizes. Cremos, ainda, que o aumento da consciência fonológica dos segmentos vocálicos em inglês possa ser um caminho viável para que aprendizes brasileiros entendam melhor como esses sons funcionam na Língua Inglesa e, assim, passem a produzi-los de forma mais adequada.

\section{REFERÊNCIAS}

ALVES, U. K. Consciência dos aspectos fonético-fonológicos da L2. In: LAMPRECHT, R. R. (org.). Consciência dos sons da língua: subsídios teóricos e práticos para alfabetizadores, fonoaudiólogos e professores de língua inglesa. 2. ed. Porto Alegre: EDIPUCRS, 2012a. p. 169-191.

ALVES, U. K. O que é consciência fonológica. In: LAMPRECHT, R. R. (org.). Consciencia dos sons da lingua: subsídios teóricos e práticos para alfabetizadores, fonoaudiólogos e professores de língua inglesa. 2. ed. Porto Alegre: EDIPUCRS, 2012b. p. 29-41.

ALVES, U. K. Teoria dos sistemas dinâmicos e desenvolvimento fonético-fonológico em uma nova língua. In: ORTIZ-PREUSS, E.; FINGER, I. (org.). $A$ dinâmica do processamento bilingue. Campinas: Pontes, 2018. p. 117-161. 
ALVES, U. K.; BARRETO, F. M. O processamento e a produção dos aspectos fonético-fonológicos da L2. In: LAMPRECHT, R. R. (org.). Consciência dos sons da língua: subsídios teóricos e práticos para alfabetizadores, fonoaudiólogos e professores de língua inglesa. 2. ed. Porto Alegre: EDIPUCRS, 2012. p. 193-209.

ARCHIBALD, J. Transfer, contrastive analysis and interlanguage phonology. In: KANG, I.; THOMSON, R. I.; MURPHY, J. M. (ed.). The Routledge Handbook of Contemporary English Pronunciation. London: Routledge, 2018. p. 9-24.

ASHTON, H.; SHEPHERD, S. Work on your accent: clearer pronunciation for better communication. London: Harper Collins Publishers, 2012.

BALAS, A. English centering diphthong production by Polish learners of English. Research in Language, v. 7, i. 1, p. 129-148, 2009.

BAYLEY, R. Second language acquisition and sociolinguistic variation. Intercultural Communication Studies, v. 14, i. 2, p. 1-15, 2005.

BEEBE, L. The influence of the listener on code-switching. Language LearningA journal of Research in Language Studies, v. 27, n. 2, p. 331-339, 1977.

CELCE-MURCIA, M.; BRINTON, D. M.; GOODWIN, J. M. Teaching pronunciation: a course book and reference guide. $2^{\text {nd }}$ ed. New York, NY: Cambridge University Press, 2010 .

CHARD, D. J.; DICKSON, S. V. Phonological awareness: Instructional and assessment guidelines. Intervention in School and Clinic, v. 34, i. 5, p. 261-270, May 1999.

CRIOULO. Dicio. Dicionário Online de Português. Acepção 6. Disponível em: bit.ly/3dDjxkWcrioulo. Acesso em: 16 fev. 2019.

CRISTÓFARO-SILVA, T. Proníncia do inglês: para falantes do português brasileiro. São Paulo: Contexto, 2012.

DAS, K. Production of central vowels and centering diphthongs by Assamese speakers of English. Northeast Journal of Contemporary Research, v. 1, i. 1, p. 55-64, May 2014.

DAVENPORT, M.; HANNAHS, S. J. Introducing phonetics \& phonology. $2^{\text {nd }}$ ed. London: Hodder Education, 2005.

ECKMAN, F. R. On the naturalness of interlanguage phonological rules. Language Learning - A Journal of Research in Language Studies, v. 30, n. 1, p. 195-216, June 1981. 
ECKMAN, Fred R. Theoretical L2 phonology. In: KANG, I.; THOMSON, R. I.; MURPHY, J. M. (ed.). The Routledge Handbook of Contemporary English Pronunciation. London: Routledge, 2018. p. 25-38.

ELLIS, R. Understanding second language acquisition. Oxford: Oxford University Press, 1986.

ELLIS, R. Interlanguage variability in narrative discourse: Style shifting in the use of past tense. Studies in Second Language Acquisition, v. 9, i. 1, p. 1-20, 1987.

ELLIS, R. The study of second language acquisition. Oxford: Oxford University Press, 1994.

ERDENER, V.D.; BURNHAM, D. K. The role of audiovisual speech and orthographic information in nonnative speech production. Language Learning, v. 55, i. 2, p. 191-228, June 2005.

FRASER, H. Phonetics, phonology, and the teaching of pronunciation: a new CD-ROM for ESL learners, and its rationale. AUSTRALIAN INTERNATIONAL CONFERENCE ON SPEECH SCIENCE AND TECHNOLOGY, 8., 2000, Canberra. In: Proceedings of SST 2000. p. 180-185. Disponível em: bit.ly/3dDN2Dcfraser. Acesso em: 20 maio 2018.

KEYS, K. J. State of the art: interlanguage phonology - factors and processes in the development of a second language phonology. Revista Brasileira de Linguística Aplicada, Belo Horizonte, v. 1, n. 1, p. 155-190, 2001. Disponível em: bit.ly/2UNnjPYKeysKJ. Acesso em: 09 maio 2018.

LABOV, W. Padrões sociolinguisticos. Tradução Marcos Bagno; Maria Marta Pereira Scherre; Caroline Rodrigues Cardoso. São Paulo: Parábola, 2008 [1972].

LADEFOGED, P. Vowels and consonants: an introduction to the sounds of languages. $2^{\text {nd }}$ ed. Oxford: Blackwell Publising, 2005.

MORI, A. C. Fonologia. In: MUSSALIM, F.; BENTES, A. C. (org.). Introdução à Lingüistica: domínios e fronteiras. São Paulo: Cortez, 2000. p. 147-179.

MOUSA, A. Acquisition of the Closing Diphthongs / $\partial v /$ and / $\mathrm{e} /$ in English L2 and Jamaican Creole: a comparative study. SAGE Open, p. 1-15, Apr. 2015. Disponível em: https://bit.ly/3it7APV. Acesso em: 25 maio 2018.

PIDGIN. Michaelis On-line. Dicionário Brasileiro da Língua Portuguesa. 2019.

Disponível em: bit.ly/3bBNdx2pidgin. Acesso em: 16 fev. 2019.

ROACH, P. English Phonetics and Phonology: a practical course. $4^{\text {th }}$ ed. New York, NY: Cambridge University Press, 2009 [1983]. 
SANKOFF, D.; TAGLIAMONTE, S. A.; SMITH, E. Goldvarb X: A variable rule application for Macintosh and Windows. Department of Linguistics, University of Toronto. 2005. Disponível em: bit.ly/3as54Glgoldvarb. Acesso em: 25 ago. 2018.

SELINKER, L. Interlanguage. IRAL - International Review of Applied Linguistics in Language Teaching, v. 10, i. 3, p. 209-231, 1972.

SELINKER, L.; DOUGLAS, D. Wrestling in 'context' with Interlanguage Theory. Applied Linguistics, v. 6, i. 2, p. 190-204, 1985.

SMITH, J.; MARGOLIS, A. Pronunciation: English for academic study. Reading, UK: University of Reading; Garnet Education, 2012.

TARONE, E. Variability in interlanguage use: A study of style-shifting in morphology and syntax. Language Learning, v. 35, p. 373-403, 1985.

TREHEARNE, M. P. Phonological Awareness. In: TREHEARNE, M. P. Comprehensive literacy resource for kindergarten teachers. Chicago, IL: ETA Cuisenaire, 2003. p. 118-152.

ZIMMER, M. C.; ALVES, U. K. A produção de aspectos fonético-fonológicos da segunda língua: instrução explícita e conexionismo. Linguagem \& Ensino, v. 9, n. 2, p. 101-143, jul./dez. 2006. 